\title{
SPATIAL SEPARATION OF THE IONES OF A GIVEN MASS RANGE IN THE DEMO-IMITATION SEPARATOR AT THE FIRST TURN OF IONIC TRAJECTORY
}

\author{
V.V. Katrechko, V.B. Yuferov, V.O. Ilichova, S.N. Khizhnyak \\ National Science Center "Kharkov Institute of Physics and Technology”, Kharkiv, Ukraine \\ E-mail:v.yuferov@kipt.kharkov.ua
}

Plasma methods, where only electricity is required, are an alternative to the PUREX process used in industry for spent nuclear fuel reprocessing. It is considered the possibility of filtering out the target ions $(\mathrm{M}=232 \ldots 277)$ to the collector at the first turn of the ion trajectory in the plasma mass filter, which is currently being developed, that is achieved by specifying certain parameters (amplitude and frequency) for a variable component of a radial electric field. This approach significantly reduces the thermal load onto deposition surface of target ions.

PACS: $28.41 . \mathrm{Kw}$

\section{INTRODUCTION}

One of the important components of the energy production process at nuclear power plants is fuel burnup. Since a burnup of nuclear fuel, consisting, as a rule, of uranium dioxide $\mathrm{UO}_{2}$, is incomplete, the urgent problem is fuel recycling or re-use of $\mathrm{UO}_{2}$ and transuranics with their oxides, which are present in spent nuclear fuel (SNF). Plasma methods are alternative techniques to the radiochemical technologies used in SNF reprocessing [1 - 3] at fuel separation from fission products (FPs). The perspective trend is development of separators with plasma rotating in crossed $\mathrm{E} \times \mathrm{B}$ fields, in particular plasma filters of masses [4 - 8].

\section{PARAMETERS OF AN ALTERNATING ELECTRIC FIELD FOR SEPARATION OF TARGET IONS IN THE DEMO-IMITATION SEPARATOR}

Note, that, except of FPs, irradiated uranium oxide fuel consists of actinides and their oxides in a range of masses: $M=232 \ldots 277$. In [9] the conceptual design of demo-imitation separator is presented where nonradioactive oxide mixture is used for SNF simulation. The separator is based on the technologies of plasma mass filter and ion cyclotron heating. Induction of magnetic field in the separation area is $B\left[B_{z}\right.$ (const)] = $0.1 \mathrm{~T}$, the electric field is provided by a system of coaxial electrodes $\left(E_{r}=E_{0}=400 \mathrm{~V} / \mathrm{m}\right)$. To filter out the ions of a given mass range $(\mathrm{M}=232 . .277)$ in a localized area of the plasma mass filter, the so-called "pocket"collector (a buffer enlarged area) it is required to add alternating electric field by means of an external RF generator with a frequency that is tuned to the frequency of the target ions:

$$
\mathrm{E}_{\mathrm{r}}=\mathrm{E}_{0}+\mathrm{k} \cdot \mathrm{E}_{0} \sin (\omega \mathrm{t})
$$

where $\mathrm{k}$ is amplitude coefficient of alternating electric field; $\omega$ is angular frequency of alternating electric field; $\mathrm{t}$ - time.

Thus, it is necessary to set the parameters of a variable component of radial electric field (amplitude and frequency), which will ensure motion of target ions to the corresponding collector.
According to our assumptions, in SNF plasma the main components would be the ions of uranium-238. Calculations of ionic trajectories for $\mathrm{M}=232 \ldots 277$ show that the variable component of electric field tuned to the frequency, $\omega$, equal to half the cyclotron frequency for singly charged ions $\mathrm{U}^{+}(\mathrm{M}=238, \mathrm{~B}=0.1 \mathrm{~T})$, with $\mathrm{k}=0.7$ provide filtering out the target ions onto the collector at the second turn (at guiding center motion in a radial direction) of ionic trajectory [10]:

$$
\omega=0.5 \mathrm{eV} / \mathrm{M} \text {. }
$$

At given parameters, the target ions reach the "pocket"-collector with an increase of the kinetic energy up to $\sim 500 \mathrm{eV}$ [9]. In this case, FP ions move along the chamber to the end collector. The length of the collector for target ions is $1 \mathrm{~m}$, with the location along z-axis of the vacuum chamber from 2.5 to $3.5 \mathrm{~m}$, and a height of $0.1 \mathrm{~m} \mathrm{[10].}$

\section{CONDITIONS FOR SPATIAL SEPARATION OF TARGET IONS AT THE FIRST TURN OF IONIC TRAJECTORY}

It is of interest to solve the task of separating the target ions at the first turn of ionic trajectory in the plasma mass filter under consideration. To do this, it is sufficient to increase the amplitude coefficient of the variable component of a radial electric field, in particular, by setting $\mathrm{k}=1$. The analysis of the ionic trajectories (Fig. 1) indicates that it is expedient to use the source with an axial plasma injection $\left(\alpha=0^{\circ}\right)$ into the vacuum chamber of the demo-imitation separator.

At the same time lowering of a kinetic energy (Fig. 2) for the ions $(M=232 \ldots 277)$, filtered out onto the collector, isachieved (from $\sim 500$ to $\sim 300 \mathrm{eV}$, compared to [9 - 10]). In this case the "pocket"-collector should be located from 1 to $2 \mathrm{~m}$ along z-axis of the separator at a radius of $1 \mathrm{~m}$ (Figs. 3-5).

From Figs. 3-5 it follows, that, as well in the case [10], there are limitations on the scatter of the angle, energy and radius related to the initial conditions for the ion motion, that must be taken into account when creating the plasma source. 


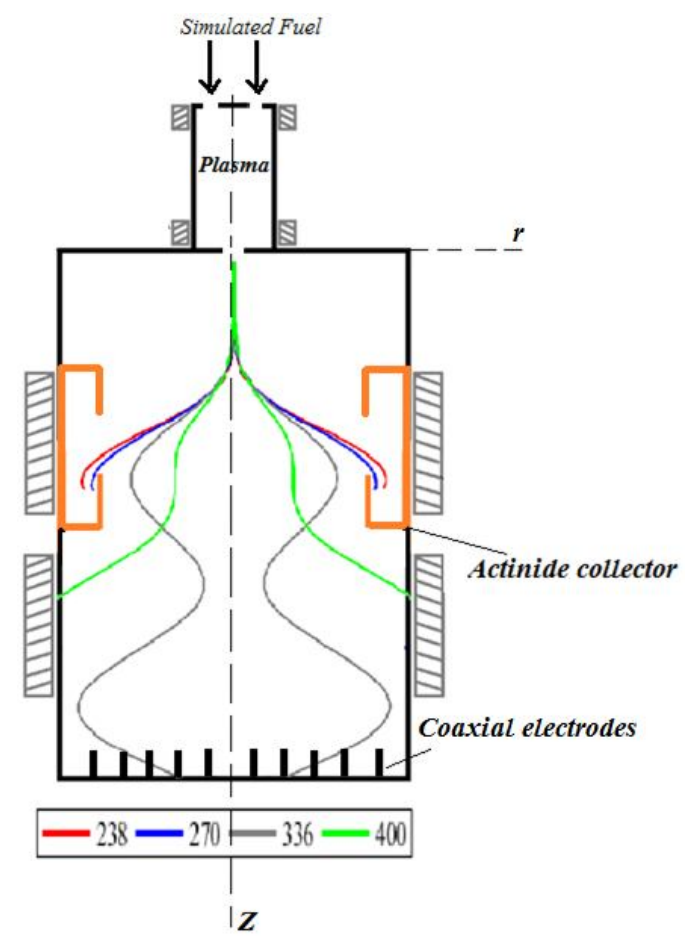

Fig. 1. Design of demo-imitation separator (DIS series [3, 9]), vertical arrangement) with trajectories for: ions of multicomponent oxides (400 a.m.u); $\mathrm{Nd}_{2} \mathrm{O}_{3}{ }^{+}$(336 a.m.u); $\mathrm{UO}_{2}{ }^{+}$(270 a.m.u); $U^{+}$(238 a.m.u) at initial conditions of ion motion: $W=5 \mathrm{eV}, \alpha=0^{\circ}, r(0)=1 \mathrm{~cm}$

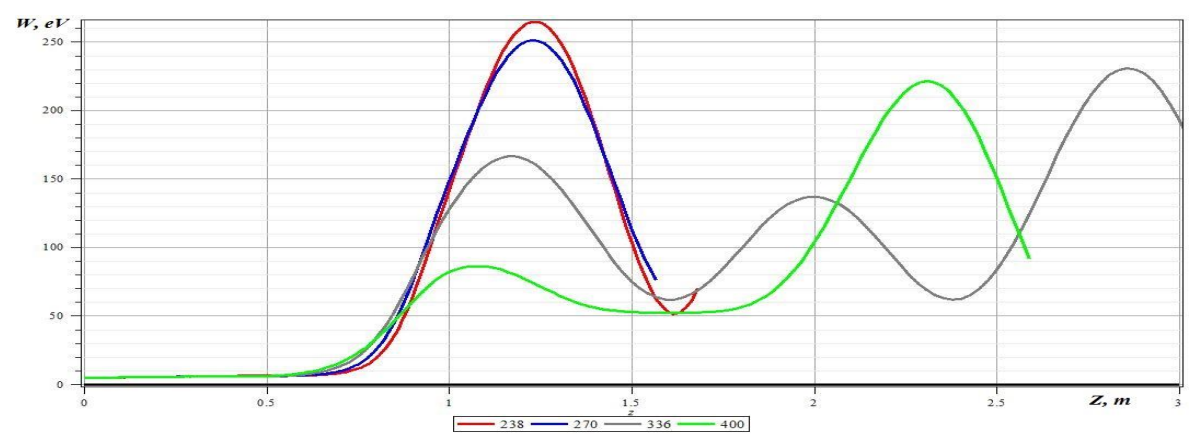

Fig. 2. The values of kinetic energy in DIS setup for ions: $M=238 ; 270 ; 336 ; 400$ at initial conditions of ion motion: $W=5 \mathrm{eV}, \alpha=0^{\circ}, \mathrm{r}(0)=1 \mathrm{~cm}$

Initial angle range, $\alpha\left(-30 \ldots+30^{\circ}\right)$
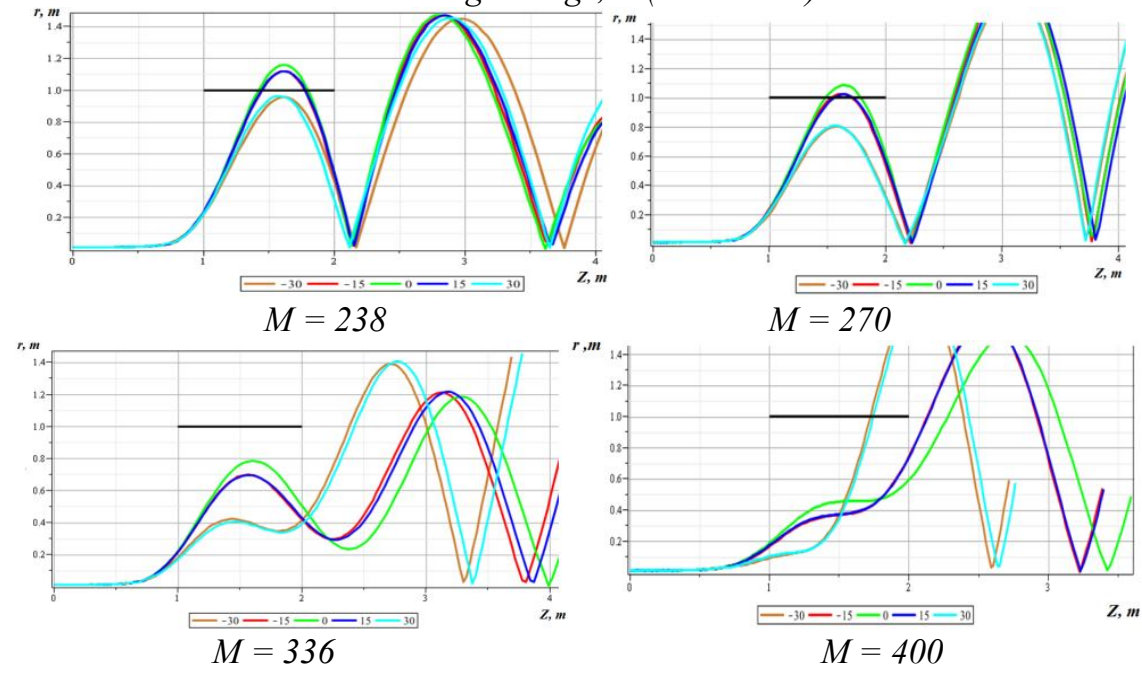

Fig. 3. Projections of the ion trajectories in $r \times z$ plane for ions: $M=238 ; 270 ; 336 ; 400(k=1, \alpha=0, r(0)=1 \mathrm{~cm})$ 

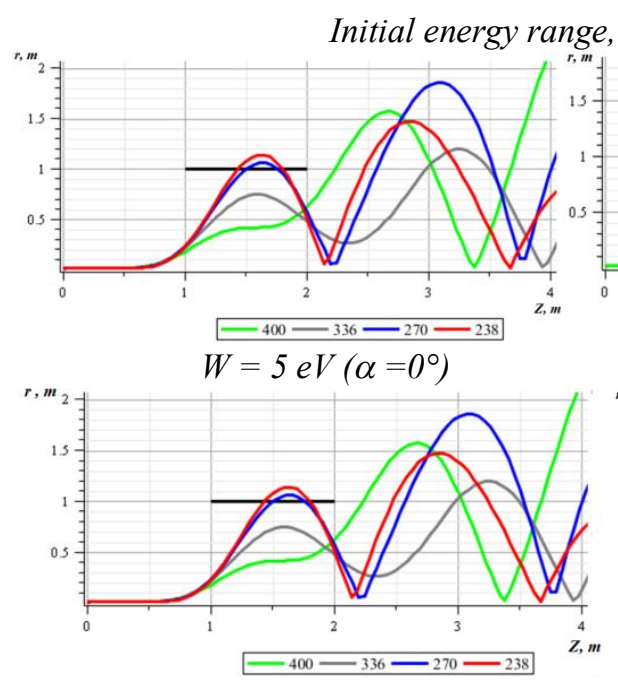

$$
W=5.5 \mathrm{eV}\left(\alpha=0^{\circ}\right)
$$

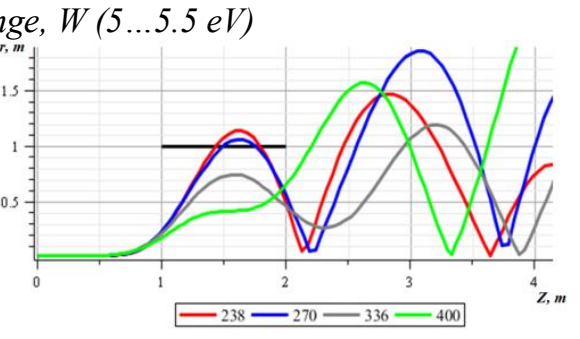

$W=5 \mathrm{eV}\left(\alpha=10^{\circ}\right)$

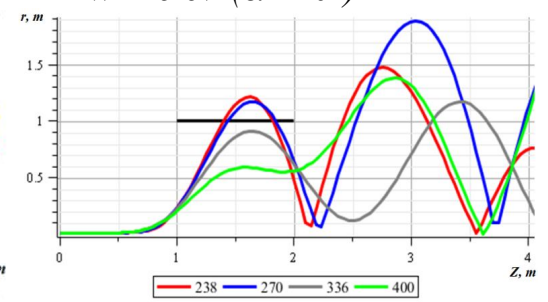

$$
W=5.5 \mathrm{eV}\left(\alpha=10^{\circ}\right)
$$

Fig. 4. Projections of the ion trajectories in $r \times z$ plane for ions: $M=238 ; 270 ; 336 ; 400(k=1$, $r(0)=1 \mathrm{~cm}, \alpha=0^{\circ}$ and $\alpha=10^{\circ}$ )

Initial radius range, $r(0.5 \ldots 1.5 \mathrm{~cm})$ :
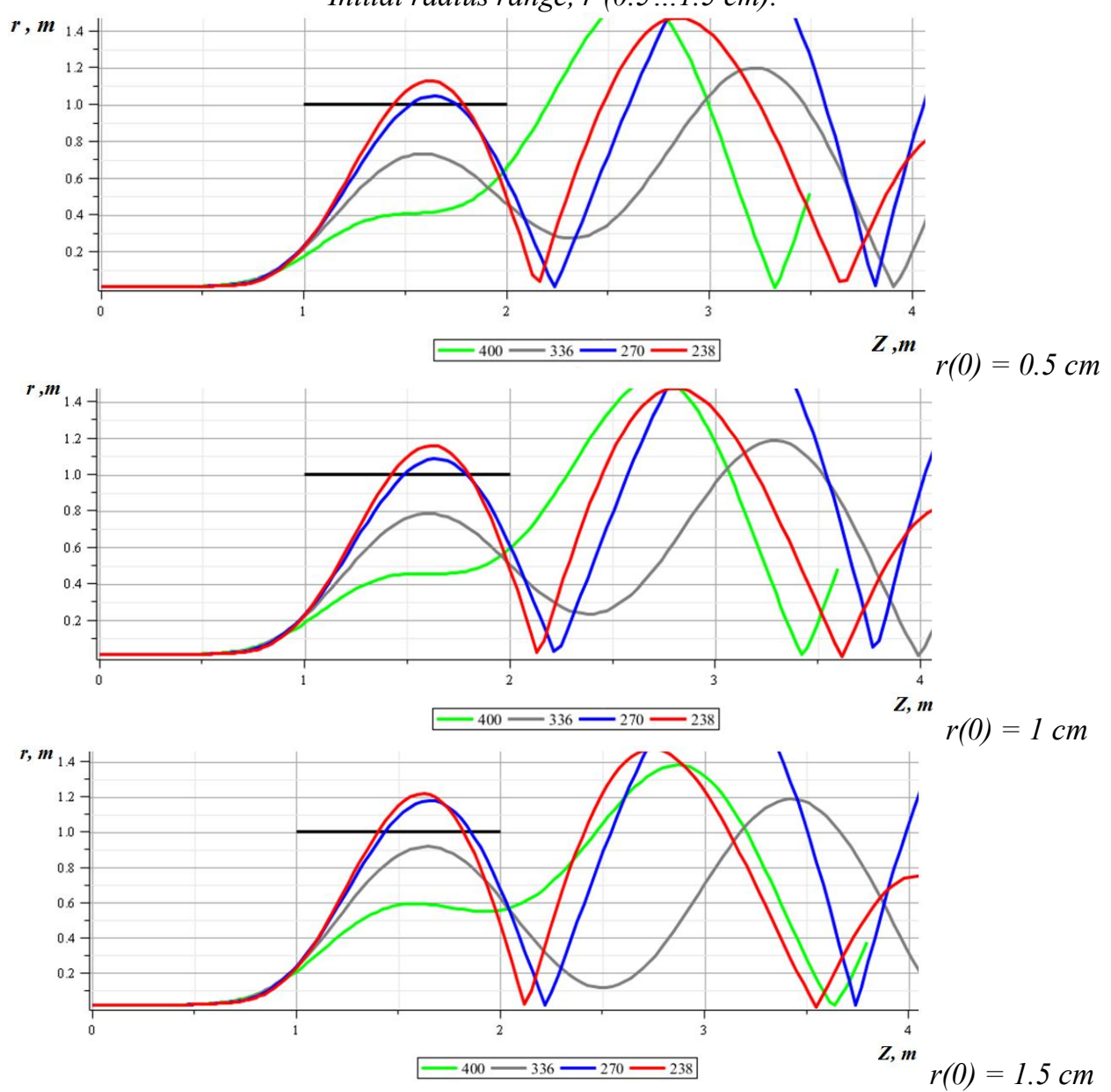

Fig. 5. Projections of the ion trajectories in $r \times z$ plane for ions: $M=238 ; 270 ; 336 ; 400\left(k=1, \alpha=0^{\circ}\right)$

The allowable scatter of the initial values for the ions $(\mathrm{M}=232 \ldots 277)$, at which their entry into the "pocket"-collector is achieved: energy, $\mathrm{W}=5 . .5 .5 \mathrm{eV}$, angle, $\alpha=0 \ldots 10^{\circ}$, radius, $r=0.5 \ldots 1.5 \mathrm{~cm}$.

Due to the spatial proximity of ionic trajectories in the plasma drift area, in the $0 . .1 \mathrm{~m}$ section along $\mathrm{z}$-axis of the separator (see Figs. 3-5), ion collisions in the plasma can occur, and ionic trajectories can deviate from ones calculated in the single-particle approaching.
Therefore, in addition, calculations were performed for singly charged uranium dioxide ions $(\mathrm{M}=270)$, that, as it was assumed, would be in the majority, for the initial angles of the ion motion of $50 \ldots 80^{\circ}$. Calculations show, that uranium dioxide ions reach a radius of $1 \mathrm{~m}$ in the $1 \ldots 2 \mathrm{~m}$ section along $\mathrm{z}$-axis of the separator (Fig. 6). This confirms that the collector for target ions should be placed exactly in this zone. 


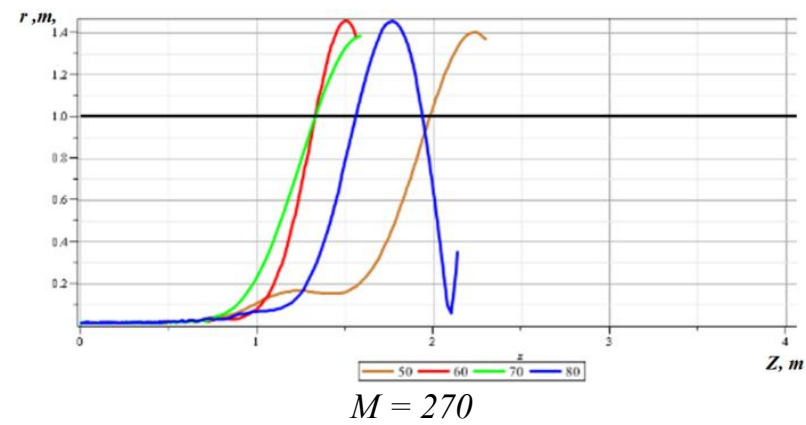

Fig. 6. Projections of the ion trajectories in $r \times z$ plane for $M=270\left(k=1, \alpha=50 \ldots 80^{\circ}\right)$

In this case, the length of the collector of target ions is $1 \mathrm{~m}$, with a location of $1 \ldots 2 \mathrm{~m}$ along the $\mathrm{z}$-axis of the vacuum chamber, a height of $0.3 \mathrm{~m}$. Thus, the area of ion deposition increases slightly compared to [9, 10], but lowering of ion energy at a level of $\sim 300 \mathrm{eV}$ could reduce the thermal load onto deposition surface for target ions about twice.

\section{CONCLUSIONS}

The availability of spatial separation for ions of a given mass range $(\mathrm{M}=232 \ldots 277)$ in the demo-imitation separator at the first turn of the ion trajectory is considered, which is achieved by setting certain parameters (amplitude and frequency) for a variable component of a radial electric field.

For the given parameters such approach at increase of amplitude coefficient $\mathrm{k}(\mathrm{k}=1$, in comparison with $\mathrm{k}=0.7$ [10]) provides filtering out the target ions onto the collector with kinetic energy at a level of $\sim 300 \mathrm{eV}$ (at ion energy decrease in 1.7 times, in comparison with $\sim 500 \mathrm{eV}$ [9]) that could prevent thermal overload on the ion deposition surface.

In addition, it is possible to reduce the length of the plasma mass filter, i.e. to make the setup compact, that is a significant advantage for the version of the separator with a vertical arrangement.

However, there are limitations on energy $5 \ldots 5.5 \mathrm{eV}$, angle $\alpha=0 \ldots 10^{\circ}$ and radius $r=0.5 \ldots 1.5 \mathrm{~cm}$, related to the initial conditions for the ion motion, which must be taken into account when creating the plasma source for the plasma mass filter, which is currently being developed.

\section{REFERENCES}

1. D.A. Dolgolenko, Yu.A. Muromkin. On separation of mixtures of chemical elements in plasma // Uspekhi Fizicheskikh Nauk. 2017, v. 187, № 10, p. 1071-1096 (in Russian).

2. S.J. Zweben, R. Gueroult, N.J. Fisch. Plasma mass separation // Physics of Plasmas. 2018, v. 25, p. 090901.

3. V.B. Yuferov, S.V. Katrechko, V.O. Ilichova, et al. Developing the Concept of Multi-Stage Spent Fuel Cleaning From Fission Products by Physical Methods // Problems of Atomic Science and Technology. Series "Vacuum, Pure Materials, Superconductors". 2018, № 1, p. 118-126.

4. A.J. Fetterman, N.J. Fisch. Plasma mass filters for nuclear waste reprocessing $2011 / / \mathrm{http} / / \mathrm{dx}$.doi.org: 10/102172/1014697.

5. John Gilleland, Tihiro Ohkawa, Stephen Agnew, et al. Application of Archimedes Filter for Reduction of Hanford HLW: WM'02 Conference, February 2428, 2002, Tucson, AZ, p. 1-8.

6. T. Ohkawa, R.L. Miller. Band gap ion mass filter // Phys. Plasmas. 2002, v. 9, № 12, p. 5116-5120.

7. V.P. Smirnov, A.A. Samokhin, N.A. Vorona, et al. Axisymmetric Plasma-Optical Mass Separators // Fizika Plasmy. 2005, v. 31, № 5, p. 458-465 (in Russian).

8. Bardakov, S.D. Ivanov, A.V. Kazantsev, N.A. Strokin. Plasma-Optical Mass Separator for Separating Substances of Complex Composition. Review // Vestnik IrGTU. Physical-Mathematical Sciences. 2014, № 3(86), p. 128-135.

9. V.B. Yuferov, V.O. Ilichova, V.V. Katrechko, et al. The conceptual design of a demo-imitation separator - the model of a plasma mass filter for irradiated oxide uranium fuel // Problems of Atomic Science and Technology. Series “Plasma Physics”. 2018, № 6, p. 289-292.

10. V.V. Katrechko, V.B. Yuferov, V.O. Ilichova, et al. Zone For Collecting The Ions Of A Given Mass Range In The Plasma Filter Of Masses // Problems of Atomic Science and Technology. Series "Nuclear Physics Investigations”. 2020, № 1, p. 185-190.

Article received 01.06.2021

\section{ПРОСТРАНСТВЕННАЯ СЕПАРАЦИЯ ИОНОВ ЗАДАННОГО ДИАПАЗОНА МАСС В ДЕМОНСТРАЦИОННО- ИМИТАЦИОННОМ СЕПАРАТОРЕ НА ПЕРВОМ ВИТКЕ ИОННОЙ ТРАЕКТОРИИ}

\section{В.В. Катречко, В.Б. Юферов, В.О. Ильичева, С.Н. Хижняк}

Альтернативой пьюрекс-процесса, который применяется в промышленности при переработке отработавшего ядерного топлива, являются плазменные технологии, где требуется только электроэнергия. Рассмотрена возможность выхода целевых ионов $(\mathrm{M}=232 \ldots 277)$ на коллектор на первом витке ионной траектории в плазменном фильтре масс, который в настоящее время разрабатывается, что достигается при задании определенных параметров (амплитуды и частоты) переменной составляющей радиального электрического поля. При таком подходе существенно уменьшается тепловая нагрузка на поверхность осаждения целевых ионов.

\section{ПРОСТОРОВА СЕПАРАЦІЯ ІОНІВ ЗАДАНОГО ДІАПАЗОНУ МАС У ДЕМОНСТРАЦІЙНО- ІМІТАЦЙНОМУ СЕПАРАТОРІ НА ПЕРШОМУ ВИТКУ ІОННОЇ ТРАЄКТОРІЇ \\ В.В. Катречко, В.Б. Юферов, В.О. Ільічова, С.М. Хіюння}

Альтернативою пьюрекс-процесу, який застосовується в промисловості при переробці відпрацьованого ядерного палива, є плазмові технології, де потрібна тільки електроенергія. Розглянута можливість виходу цільових іонів (М = 232...277) на колектор на першому витку іонної траєкторії в плазмовому фільтрі мас, котрий зараз розробляється, що досягається при завданні певних параметрів (амплітуди та частоти) змінної компоненти радіального електричного поля. При такому підході значно зменшується теплове навантаження на поверхню осадження цільових іонів. 